\title{
Recovery of Endothelial Cell
}

\section{Prostacyclin Production after Inhibition by}

\section{Low Doses of Aspirin}

\author{
Eric A. JAFFe and BABetTe B. WeKsler, Division of Hematology-Oncology, \\ Department of Medicine, Cornell University Medical College, \\ New York 10021
}

A B S T RACT Endothelial cells synthesize prostacyclin $\left(\mathrm{PGI}_{2}\right)$, an unstable prostaglandin that inhibits platelet aggregation and serotonin release. Because cyclooxygenase, which is necessary for synthesis of $\mathrm{PGI}_{2}$, is inactivated by aspirin, we examined the effect of aspirin on $\mathrm{PGI}_{2}$ production by cultured human endothelial cells. Endothelial cells synthesize $\mathrm{PGI}_{2}$ $\left(20.1 \pm 7.2 \mathrm{ng} / 10^{6}\right.$ cells, mean $\left.\pm \mathrm{SD}\right)$ when stimulated with $20 \mu \mathrm{M}$ sodium arachidonate for $2 \mathrm{~min}$. $\mathrm{PGI}_{2}$ production is inhibited by low-dose aspirin $(5 \mu \mathrm{M})$; the $\mathrm{t}_{1 / 2}$ of inactivation is $6.0 \pm 1.3 \mathrm{~min}$ (mean $\pm \mathrm{SEM}$, $n=3$ ). Thus, endothelial cell cyclooxygenase is as sensitive to aspirin as the enzyme in platelets. After $1 \mathrm{~h}$ incubation with aspirin, endothelial cell $\mathrm{PGI}_{2}$ production was inhibited $50 \%$ by $2.1 \pm 0.4 \mu \mathrm{M}$ aspirin and was inhibited $90 \%$ by $6.2 \pm 0.9 \mu \mathrm{M}$ aspirin (mean \pm SEM, $n=4)$. When endothelial cells were incubated with $100 \mu \mathrm{M}$ aspirin, washed, and recultured, their ability to synthesize $\mathrm{PGI}_{2}$ returned to control levels in $35.6 \pm 1.0 \mathrm{~h}($ mean $\pm \mathrm{SEM}, n=4)$. Recovery of endothelial $\mathrm{PGI}_{2}$ production after aspirin depended on de novo protein synthesis because treatment with cycloheximide $(3 \mu \mathrm{g} / \mathrm{ml})$ inhibited recovery by $92 \%$.

These results indicate that although endothelial

Dr. Jaffe is the recipient of a National Institutes of Health Research Career Development Award (5 KO4 HL 00237) and a Career Scientist Award from the Irma T. Hirschl Trust.

Received for publication 21 November 1978 and in revised form 15 December 1978. cell cyclooxygenase in vitro is inhibited by low concentrations of aspirin, endothelial cells rapidly resynthesize their cyclooxygenase after the aspirin is removed. This rapid resynthesis of cyclooxygenase lessens the likelihood that aspirin used in clinical doses promotes thrombosis.

\section{INTRODUCTION}

Prostacyclin $\left(\mathrm{PGI}_{2}\right)^{1}$ is a labile prostaglandin that inhibits platelet aggregation and serotonin release and causes vasodilation (1). We have recently shown that cultured human endothelial cells synthesize $\mathrm{PGI}_{2}$ when stimulated with thrombin, the calcium ionophore A23187, trypsin, or sodium arachidonate $(2,3)$. The initial step in the synthesis of $\mathrm{PGI}_{2}$ in endothelium or thromboxane $A_{2}$ in platelets from arachidonic acid is catalyzed by the enzyme cyclooxygenase. In platelets, cyclooxygenase is irreversibly inactivated by low doses of aspirin (4), and this is the basis for the use of aspirin as an antithrombotic agent. However, cyclooxygenase is also required for $\mathrm{PGI}_{2}$ synthesis from arachidonate so that inhibition of endothelial cell cyclooxygenase would decrease endothelial cell $\mathrm{PGI}_{2}$ production and might promote thrombosis. Because aspirin is now commonly used in the treatment of thrombo-embolic disorders, we have examined the effect of aspirin on endothelial cell $\mathrm{PGI}_{2}$ production.

In this paper we show that although endothelial

\footnotetext{
${ }^{1}$ Abbreviation used in this paper: $\mathrm{PGI}_{2}$, prostacyclin.
} 
cell $\mathrm{PGI}_{2}$ synthesis is indeed inhibited by low doses of aspirin, recovery of $\mathrm{PGI}_{2}$ production occurs rapidly.

\section{METHODS}

Endothelial cell monolayer cultures. Human endothelial cells derived from umbilical cord veins were cultured in replicate $35-\mathrm{mm}$ Petri dishes in medium 199 containing $20 \%$ pooled human serum, as previously described (5), and used when confluent. Cell counts in dishes used on a given day varied by $<15 \%$.

Treatment of endothelial cells with aspirin. Aspirin (Sigma Chemical Co., St. Louis, Mo.) stock solutions (0.1 M in absolute ethanol) were always freshly prepared and sterilized by filtration. Before addition to endothelial cells, the aspirin was diluted with sterile water and $0.01 \mathrm{vol}$ of diluted aspirin solution added to the culture medium to achieve the desired final concentration. The endothelial cells were incubated in $5 \% \mathrm{CO}_{2}$ at $37^{\circ} \mathrm{C}$ for varying periods of time after which the culture medium was removed and the cells washed twice with Buffer A $(10 \mathrm{mM}$ Hepes $\mathrm{pH}$ 7.3 at $37^{\circ} \mathrm{C}, 150 \mathrm{mM} \mathrm{NaCl}, 5 \mathrm{mM} \mathrm{KCl}, 1.8 \mathrm{mM} \mathrm{CaCl}_{2}, 1 \mathrm{mM}$ $\mathrm{MgCl}_{2}, 5.5 \mathrm{mM}$ glucose). The cells were then either assayed immediately for $\mathrm{PGI}_{2}$ production or washed and recultured for additional time periods and then assayed. Control endothelial cell monolayers treated with $0.1 \%$ ethanol alone were included in each series of experiments. Ethanol at this concentration had no effect on $\mathrm{PGI}_{2}$ synthesis.

Platelet preparations. Washed platelet suspensions for the thrombin release assay (see below) were prepared as previously described (3).

Assay for PGI $\mathrm{I}_{2}$ production. Monolayers of endothelial cells were washed twice with Buffer $A$ and then covered with $1 \mathrm{ml}$ of Buffer B (15 mM Tris $\mathrm{HCl}$ pH 8.6, $140 \mathrm{mM} \mathrm{NaCl}$, $5.5 \mathrm{mM}$ glucose), which preserves $\mathrm{PGI}_{2}$ activity (6). Sodium arachidonate (final concentration, $20 \mu \mathrm{M}$ ) was then added and the monolayer incubated for $2 \mathrm{~min}$ at $37^{\circ} \mathrm{C}$. Buffer $\mathrm{B}$ was then removed and either assayed immediately for $\mathrm{PGI}_{2}$ or frozen at $-70^{\circ} \mathrm{C}$ until assayed. PGI $\mathrm{I}_{2}$ activity was measured by quantitating the release of $\left[{ }^{14} \mathrm{C}\right]$ serotonin from prelabeled, washed, aspirin-treated platelet suspensions stimulated by thrombin in the presence or absence of authentic $\mathrm{PGI}_{2}$ or supernatant fluids containing $\mathrm{PGI}_{2}$. This assay system is a modification of the method of Baenziger et al. (6) and has been described previously (3). $\mathrm{PGI}_{2}$ (a gift of Dr. John Pike, Upjohn Co., Kalamazoo, Mich.) standards ranging from 0.1 to $100 \mathrm{nM}$ were included in all experiments. Because the percent change in thrombin concentration producing $50 \%$ of maximal serotonin release $\left(\Delta \mathrm{T}_{50}\right)$ varied in a dose-response fashion with $\mathrm{PGI}_{2}$ concentration, a curve of $\Delta \mathrm{T}_{50}$ vs. $\log \mathrm{PGI}_{2}$ was plotted and used to convert our $\Delta \mathrm{T}_{50}$ data to $\mathrm{PGI}_{2}$ concentration.

Cycloheximide inhibition of the recovery of $\mathrm{PGI}_{2}$ production. Endothelial cells were incubated with $100 \mu \mathrm{M}$ aspirin for $1 \mathrm{~h}$, washed, and cultured for $18 \mathrm{~h}$ with cycloheximide $(0.1,1$, or $3 \mu \mathrm{g} / \mathrm{ml}$ ) (Sigma Chemical Co.). The cells were then assayed for $\mathrm{PGI}_{2}$ production and compared to cells processed in parallel in the absence of cycloheximide.

\section{RESULTS}

Time-course of inhibition of endothelial cell PGI production by aspirin. Endothelial cells stimulated for $2 \mathrm{~min}$ with $20 \mu \mathrm{M}$ sodium arachidonate produced $20.1 \pm 7.2 \mathrm{ng} \mathrm{PGI}_{2} / 10^{6}$ cells (mean $\left.\pm \mathrm{SD}, n=4\right)$. This represents a concentration of $\mathrm{PGI}_{2}$ in the supernate

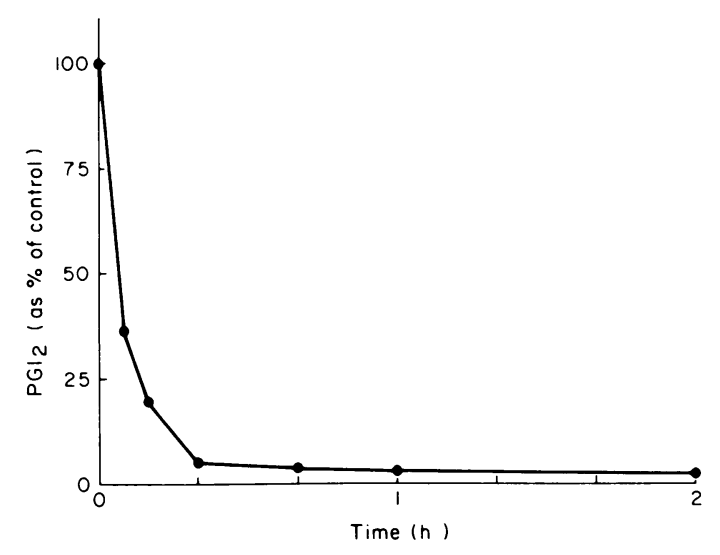

FIgure 1 Time-course of inhibition by aspirin of endothelial $\mathrm{PGI}_{2}$ production. Replicate cultures of human endothelial cells were treated with $5 \mu \mathrm{M}$ aspirin for increasing times, washed (see Methods), and then stimulated with $20 \mu \mathrm{M}$ sodium arachidonate for $2 \mathrm{~min}$. The supernatant fluids were then removed from the monolayers and assayed for $\mathrm{PGI}_{2}$ using the $\left[{ }^{3} \mathrm{H}\right]$ serotonin release assay described in Methods. The quantities of $\mathrm{PGI}_{2}$ produced are expressed as percent of aspirin-free controls.

$(1 \mathrm{ml})$ of $28.2 \pm 14.7 \mathrm{nM}($ mean $\pm \mathrm{SD})$. Inactivation of endothelial cell cyclooxygenase by aspirin was measured as the reduction in $\mathrm{PGI}_{2}$ synthesis observed after stimulation with arachidonate $(20 \mu \mathrm{M})$ for $2 \mathrm{~min}$. When endothelial cells were exposed to $5 \mu \mathrm{M}$ aspirin for varying periods of time, $\mathrm{PGI}_{2}$ production rapidly declined (Fig. 1). After $5 \mathrm{~min}$ of aspirin exposure $\mathrm{PGI}_{2}$ production fell to $36 \%$ of control values, and after $1 \mathrm{~h}$ endothelial cell $\mathrm{PGI}_{2}$ production was $<3 \%$ of control.

Because a plot of $\log \left(\mathrm{PGI}_{2}=x / \mathrm{PGI}_{2 t=0}\right)$ vs. time was linear for the first $20 \mathrm{~min}$, the experiment initially followed pseudo first order kinetics for the acetylation reaction. With calculations similar to those of Burch et al. (7), the $t_{1 / 2}$ of decrease of endothelial cell $\mathrm{PGI}_{2}$ production in the presence of $5 \mu \mathrm{M}$ aspirin was $6.0 \pm 1.3 \mathrm{~min}($ mean $\pm \mathrm{SEM}, n=3)$, and the rate constant for the inhibition of $\mathrm{PGI}_{2}$ production by $5 \mu \mathrm{M}$ aspirin $\left(K_{\text {apparent }}=[\ln 2] / \mathrm{t}_{1 / 2}\right) \quad$ was $0.116 \mathrm{~min}^{-1}$. Defining a potency term as $K_{\text {apparent }} /$ aspirin concentration (7), the inhibitory capacity of aspirin on endothelial cell $\mathrm{PGI}_{2}$ production was $23,100 / \mathrm{min}^{-1} \mathbf{M}^{-1}$. Because Burch et al. calculated a potency of aspirin toward platelet cyclooxygenase of $21,700 / \mathrm{min}^{-1} \mathrm{M}^{-1}(7)$, it appears that endothelial cells and platelets are similarly sensitive to aspirin.

Dose-response characteristics of inhibition of endothelial cell PGI ${ }_{2}$ production by aspirin. Endothelial cells were incubated with increasing doses of aspirin for $1 \mathrm{~h}$ and then assayed for $\mathrm{PGI}_{2}$ production after stimulation with $20 \mu \mathrm{M}$ sodium arachidonate. As shown in Fig. 2, $\mathrm{PGI}_{2}$ synthesis was inhibited by aspirin in a dose-dependent manner. Data obtained 


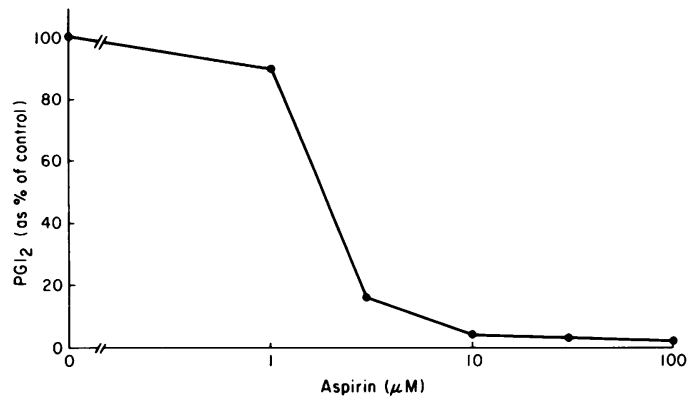

FIGURE 2 Inhibition of endothelial cell $\mathrm{PGI}_{2}$ production as a function of aspirin dosage. Replicate cultures of endothelial cells were treated with increasing doses of aspirin for $1 \mathrm{~h}$. The aspirin was removed, the cells washed, and then stimulated with $20 \mu \mathrm{M}$ sodium arachidonate for $2 \mathrm{~min}$. The supernatant fluids were removed and assayed for $\mathrm{PGI}_{2}$ activity. The amounts of $\mathrm{PGI}_{2}$ produced are expressed as percent of aspirin-free controls.

from curves of experiments such as those shown in Fig. 2 indicated that after $1 \mathrm{~h}$ endothelial cell $\mathrm{PGI}_{2}$ production was inhibited $50 \%$ by $2.1 \pm 0.4 \mu \mathrm{M}$ aspirin and inhibited $90 \%$ by $6.2 \pm 0.9 \mu \mathrm{M}$ aspirin (mean $\pm \mathrm{SEM}$, $n=4)$.

Time-course of recovery of endothelial cell PGI production after inhibition by aspirin. Replicate cultures of endothelial cells were treated with $100 \mu \mathrm{M}$ aspirin for $1 \mathrm{~h}$ at $37^{\circ} \mathrm{C}$, washed, and then recultured for varying periods. The endothelial cells were then stimulated with $20 \mu \mathrm{M}$ sodium arachidonate and assayed for $\mathrm{PGI}_{2}$ production. The results of a typical experiment are shown in Fig. 3. The ability of endothelial cells to produce $\mathrm{PGI}_{2}$ returned to control

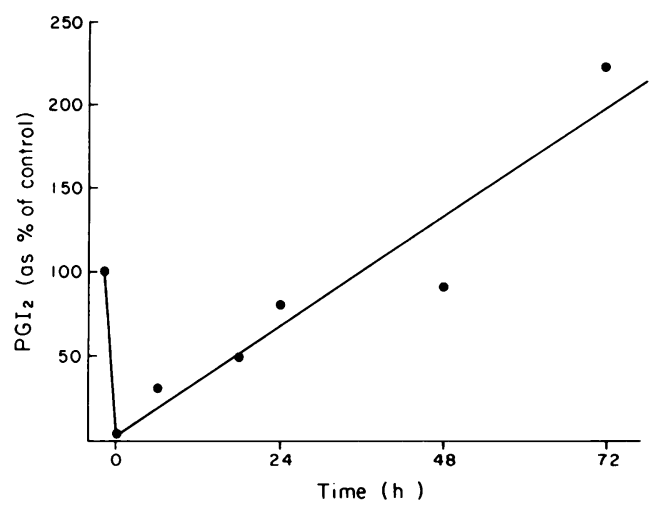

FIGURE 3 Time-course of recovery of endothelial cell $\mathrm{PGI}_{2}$ production after inhibition by aspirin. Replicate cultures of endothelial cells were treated with $100 \mu \mathrm{M}$ aspirin for $1 \mathrm{~h}$ at $37^{\circ} \mathrm{C}$, washed, and then incubated with medium 199 containing $20 \%$ human serum for increasing time intervals. The endothelial cells were then washed and stimulated with $20 \mu \mathrm{M}$ sodium arachidonate for $2 \mathrm{~min}$, and the supernatant fluids were assayed for $\mathrm{PGI}_{2}$ activity. The amounts of $\mathrm{PGI}_{2}$ produced are expressed as percent of aspirin-free controls. levels by $35 \mathrm{~h}$. Data obtained from curves of experiments such as those seen in Fig. 3 showed that after a $1 \mathrm{~h}$ incubation with $100 \mu \mathrm{M}$ aspirin, endothelial cell $\mathrm{PGI}_{2}$ production returned to control levels in $35.6 \pm 1.0 \mathrm{~h}$ (mean $\pm \mathrm{SEM}, n=4)$. In three additional experiments in which recovery was monitored from 0 to $24 \mathrm{~h}$, recovery curves were similar to those seen in Fig. 3. By extrapolation these curves yielded an estimated recovery time of $37.6 \pm 4.9 \mathrm{~h}$ (mean $\pm \mathrm{SEM}$, $n=3$ ) which is consistent with the 36 -h recovery time obtained in our other experiments.

Resumption of endothelial cell $\mathrm{PGI}_{2}$ production after inhibition by aspirin was dependent on new protein synthesis. Cycloheximide inhibited the recovery of $\mathrm{PGI}_{2}$ production in a dose-related fashion; thus cycloheximide $(3 \mu \mathrm{g} / \mathrm{ml})$ inhibited recovery of $\mathrm{PGI}_{2}$ production by $92 \%$.

\section{DISCUSSION}

Pharmacologic studies in man have shown that 650 $\mathrm{mg}$ of aspirin given orally will yield plasma aspirin levels of $128 \mu \mathrm{M}$ at $10 \mathrm{~min}, 56 \mu \mathrm{M}$ at $25 \mathrm{~min}$, and 18 $\mu \mathrm{M}$ at $1 \mathrm{~h} \mathrm{(8)}$. Our data (i.e., $6.2 \mu \mathrm{M}$ aspirin for $1 \mathrm{~h}$ inhibits endothelial cell $\mathrm{PGI}_{2}$ production by $90 \%$ ) indicate that endothelial cell $\mathrm{PGI}_{2}$ production is promptly inhibited by doses of aspirin comparable to those employed clinically. This is also true of platelet thromboxane $\mathrm{A}_{2}$ production (7). It thus appears that endothelial cell and platelet cyclooxygenases are equally sensitive to aspirin inhibition. Endothelial cells begin to regain their ability to produce $\mathrm{PGI}_{2}$ as soon as aspirin is removed (Fig. 3) and recover fully by $\cong 36 \mathrm{~h}$. In marked contrast, however, platelets never regain cyclooxygenase activity after aspirin because acetylation of the enzyme is not reversible (7). The platelet cyclooxygenase, which becomes measurable $48 \mathrm{~h}$ after aspirin, represents that present in newly formed platelets (7). Thus, during the first $48 \mathrm{~h}$ after aspirin treatment, endothelial cells can produce $\mathrm{PGI}_{2}$, whereas platelets cannot produce thromboxane $\mathrm{A}_{2}$. Recovery of endothelial $\mathrm{PGI}_{2}$ production after aspirin reflects new protein synthesis inasmuch as it is inhibited by cycloheximide.

In the early stages of recovery from aspirin inhibition, endothelial cell $\mathrm{PGI}_{2}$ production may be $<10 \%$ of normal (i.e., $10 \%$ of $28.2 \mathrm{nM}$ or $2.8 \mathrm{nM}$ in our culture system). The surface:volume ratio of the human vascular system $\left(1,000 \mathrm{~m}^{2} / 3,500 \mathrm{ml}=2.86 \times 10^{3} \mathrm{~cm}^{2} /\right.$ $\mathrm{ml})^{2}$ is much greater than this ratio in a $35-\mathrm{mm}$ Petri dish $\left(9.6 \mathrm{~cm}^{2} / 1 \mathrm{ml} \cong 9.6 \mathrm{~cm}^{2} / \mathrm{ml}\right)$. Thus in vivo production of $\mathrm{PGI}_{2}$ at $10 \%$ of maximum could theoretically yield a peak blood $\mathrm{PGI}_{2}$ concentration of $\cong 830 \mathrm{nM}$

\footnotetext{
${ }^{2}$ Assuming an average vascular surface area of $1,000 \mathrm{~m}^{2}(9)$ and an average plasma volume of $3,500 \mathrm{ml}$.
} 
$\left(2.8 \mathrm{nM} \times 2.86 \times 10^{3} / 9.6\right)$. In vitro, such levels of $\mathrm{PGI}_{2}$ have a profound inhibitory effect on platelet behavior. For example, $1.4 \mathrm{nM} \mathrm{PGI}$ fully inhibited thrombus formation, and $57 \mathrm{nM} \mathrm{PGI}$ inhibited platelet adhesion by $56 \%$ when human blood was exposed to rabbit aorta subendothelium (10). Furthermore, $47 \mathrm{nM}$ $\mathrm{PGI}_{2}$ caused a half-maximal increase in platelet cyclic AMP to a level of $\cong 12$ times basal level (11) when only a doubling of cyclic AMP was needed to inhibit platelet aggregation (12). Similarly, we have reported that $0.1 \mathrm{nM} \mathrm{PGI}_{2}$ completely inhibited platelet aggregation in platelet-rich plasma induced by threshold levels of arachidonic acid (3). Thus, in man and experimental animals even a small fraction of the productive capacity for $\mathrm{PGI}_{2}$ in normal blood vessels should result in more than enough $\mathrm{PGI}_{2}$ to inhibit platelet function.

Recent animal studies support our contention that the effect of aspirin on endothelial cyclooxygenase is of brief duration. In rabbits, $\mathrm{PGI}_{2}$ mediated decrease in thrombus size after standardized vascular injury was observed as soon as $2.5 \mathrm{~h}$ after infusion of aspirin $(200 \mathrm{mg} / \mathrm{kg})(13)$. Also, in rats given lysine acetylsalicylate $(200 \mathrm{mg} / \mathrm{kg}), \mathrm{PGI}_{2}$ production in veins returned to $51 \%$ of control in $24 \mathrm{~h}$ and to normal levels in $48 \mathrm{~h} \mathrm{(14).}$

In summary, endothelial cell $\mathrm{PGI}_{2}$ synthesis is inhibited by low doses of aspirin, but recovery to control levels occurs by $36 \mathrm{~h}$. The ability of endothelial cells in normal blood vessels to produce $\mathrm{PGI}_{2}$ seems to be far in excess of that needed to inhibit platelet function. Our data thus suggest that aspirin as used in clinical practice will not paradoxically promote thrombosis. We do, however, suggest that in patients with normal platelet turnover, aspirin administration be limited to once a day.

\section{ACKNOWLEDGMENTS}

We thank Christopher Ley, Tina Pavane, Emily Altman, Charles Dorso, Karen Tack-Goldman, and Andrea Frank for excellent technical assistance and Naomi Nemtzow for typing the manuscript.

This work is supported by the National Institutes of Health through a specialized Center for Thrombosis Re- search grant (HL 18828), the New York Heart Association, and the Arnold R. Krakower Hematology Foundation.

\section{REFERENCES}

1. Moncada, S., and J. R. Vane. 1978. Unstable metabolites of arachidonic acid and their role in haemostasis and thrombosis. Br. Med. Bull. 34: 129-135.

2. Weksler, B. B., A. J. Marcus, and E. A. Jaffe. 1977. Synthesis of prostaglandin $\mathrm{I}_{2}$ (prostacyclin) by cultured human and bovine endothelial cells. Proc. Natl. Acad. Sci. U. S. A. 74: 3922-3926.

3. Weksler, B. B., C. W. Ley, and E. A. Jaffe. 1978. Stimulation of endothelial cell prostacyclin $\left(\mathrm{PGI}_{2}\right)$ production by thrombin, trypsin, and the ionophore A23187. J. Clin. Invest. 62: 923-930.

4. Roth, G. J., N. Stanford, and P. W. Majerus. 1975. Acetylation of prostaglandin synthetase by aspirin. Proc. Natl. Acad. Sci. U. S. A. 72: 3073-3076.

5. Jaffe, E. A., R. L. Nachman, C. G. Becker, and C. R. Minick. 1973. Culture of human endothelial cells derived from umbilical cord veins. Identification by morphologic and immunologic criteria. J. Clin. Invest. 52: 2745-2756.

6. Baenziger, N. L., M. J. Dillender, and P. W. Majerus. 1977. Cultured human skin fibroblasts and arterial cells produce a labile platelet-inhibitory prostaglandin. Biochem. Biophys. Res. Commun. 78: 294-301.

7. Burch, J. W., N. Stanford, and P. W. Majerus. 1978. Inhibition of platelet prostaglandin synthetase by oral aspirin. J. Clin. Invest. 61: 314-319.

8. Rowland, M., S. Riegelman, P. A. Harris, and S. D. Sholkoff. 1972. Absorption kinetics of aspirin in man following oral administration of an aqueous solution. J. Pharm. Sci. 61: 379-385.

9. Falkow, B., and E. Neil. 1971. Circulation. Oxford University Press, New York. 38.

10. Higgs, E. A., S. Moncada, J. R. Vane, J. P. Caen, H. Michel, and G. Tobelem. 1978. Effect of prostacyclin $\left(\mathrm{PGI}_{2}\right)$ on platelet adhesion to rabbit arterial subendothelium. Prostaglandins. 16: 17-22.

11. Gorman, R. R., S. Bunting, and O. V. Miller. 1977. Modulation of human platelet adenylate cyclase by prostacyclin (PGX). Prostaglandins. 13: 377-388.

12. Tateson, J. R., S. Moncada, and J. R. Vane. 1977. Effects of prostacyclin (PGX) on cyclic AMP concentrations in human platelets. Prostaglandins. 13: 389-397.

13. Kelton, J. G., J. Hirsch, C. J. Carter, and M. R. Buchanan. 1978. Thrombogenic effect of high-dose aspirin in rabbits. Relationship to inhibition of vessel wall synthesis of prostaglandin $\mathrm{I}_{2}$-like activity. J. Clin. Invest. 62: 892-895.

14. Livio, M., S. Villa, and G. DeGaetano. 1978. Aspirin, thromboxane, and prostacyclin in rats: a dilemma resolved? Lancet. I: 1307. 